\title{
Potential Use of Misoprostol in Obstetrics and Gynaecology
}

\author{
Varsha Kotwal* \\ Senior Consultant, Obstetrics and Gynaecology, Distt. Hospital Doda, India
}

Submission: April 27, 2019; Published: May 09, 2019

*Corresponding author: Varsha Kotwal, Senior Consultant, Obstetrics and Gynaecology, Distt. Hospital Doda, Jammu and Kashmir, India

\begin{abstract}
Misoprostol is a synthetic prostaglandin E1 analogue that is used off label for a variety of purposes in the practice of Obstretics and gynaecology which includes medical termination of pregnancy, medical management of abortion, artificial induction of labour, ripenng ofcervix before surgical procedures, and the treatment of postpartum haemorrhage. So, due to its wide-ranging applications in reproductive health, misoprostol is on the model lst of essential medicines of world health organization. The man focus of this article is to briefly review the potential use of misoprostol in Obstetics and Gynaecology.
\end{abstract}

Keywords: Misoprostol; Prostaglandin; Heamorrhage; Gynaecology

\section{Introduction}

Misoprostol is sold under the brand name Cytotec. It is a medication which is used to prevent and treat stomach ulcers, induce labour, cause an abortion and treat postpartum haemorrhage due to poor contraction of uterus [1]. Its effectiveness for abortion is between $66 \%$ and $90 \%$ and s often used with mifepristone or methotrexate [2]. It's administered orally to treat gastric ulcers but for labour induction or abortion, it is taken either in the cheek, under the tongue or places in vagina [3-5] The effects of misoprostol are dose dependent and it includes cervical softening and dilation, contraction of uterus, nausea, vomiting, diarrhea, fever and chills [1]. However, it has various other advantages over other synthetic prostaglandins analogues like its low cost, long shelf life, lack of need of refrigerator and its worldwide availability.

\section{Routes of Administration of Misoprostol}

Various routes of administration are oral, vaginal, sublingual, buccal or rectal. Comparison of oral and vaginal administration have shown that vaginal administration is associated with slower absorption. It is also associated with overall greater exposure to drug and greater effects on cervix and uterus. Sublingual pattern shows greater absorption and high peaks levels. Buccal pattern shows lower area under the curve and has lower side effects. Nonetheless buccal and vaginal routes have similar effects on uterine tone and activity.

\section{Medical Abortion}

$600 \mathrm{mg}$ of oral mifepristone with $400 \mu \mathrm{g}$ of oral misoprostol 48 hrs later for pregnancies up to 49 days of gestation is approved by
FDA in 2000. Success rate of these regimes ranges from $95 \%$ to $98 \%$ with failure due to ongoing pregnancy is $1 \%$ approximately. Medical termination of pregnancy accessorily involves heavy bleeding and cramping as the pregnancy is expelled. Other side effects include nausea, vomiting, fever and chills. The death rate for mifepristone abortion is 1 per 100000 women, that too due to fatal sepsis [6]. When mifepristone is not available, misoprostol is used alone. Cervical ripening before surgical abortion: misoprostol is a proven cervical ripening agent prior to first trimester surgical abortion [7]. studies have shown that its possible dose s $400 \mu \mathrm{g}$ [8]. routes of administration can be oral, vaginal, sublingual.

\section{Use of Misoprostol in Hysteroscopy}

The main aim of using misoprostol in hysteroscopy $s$ to prevent complications of mechanical dilations such as cervical laceration, uterine perforation and creation of false passage 50 . Studies have shown that misoprostol leads to a much greater dilation, decreased need of more dilation and reduced the rate of cervical laceration $n$ premenopausal women51. The greatest benefits were seen $\mathrm{n}$ nulliparous women and with operative hysteroscopy.

\section{Induction of Labour With A Viable Fetus}

In comparison with placebo, misoprostol causes cervical ripening before induction with oxytocin8182. It is administrated vaginally, and the used dose is $25 \mu$ g every 4 hours as needed, with a maximum dose of $150 \mu$ g 85. Primary outcomes included rate of vaginal delivery within 24 hours, incidences of uterine hyperstimulation with fetal heart rate changes, rate of cesarean delivery, and risk of serious adverse event in mother or fetus. 


\section{Post-Partum Haemorrahage}

Apart from its uterine properties, misoprostol s used to treat post-partum haemorrahages [9]. Studies have shown that $1000 \mu \mathrm{g}$ of rectal administration of misoprostol when given to patientscontrolled post-partum hemorrhage within 3 minutes 94 .

\section{Conclusion}

In a nutshell, misoprostol has many implications in obstrectics and gynaecology. Research is going on its potential use to apply in different complications. Its low cost and easy use make it a potential drug to improve women's health worldwide.

\section{References}

1. Rostom A, Dube C, Wells G, Tugwell P, Welch, et al. (2002) Prevention of NSAID- induced gastroduodenal ulcers. database of systematic (4): CD002296.

2. Kulier R, Kapp N, Gulmezoglu AM, Hofmeyr GJ, Cheng L, et al. (2011) Medical methods for first trimester abortion. The Cochrane database syst reviews (11): CD002855.
3. Marret H, Simon E, Beucher G, Dreyfus m, Gaudineau A, et al. (2015) Overview and expert assessment of off- label use of msoprostol $\mathrm{n}$ obstetrics and gynaecology: review and report by the college national des gynecologues obstetriciens francais. European Journal of Obstetrics, Gynecology, and Reproductive Biology 187: 80-84.

4. Goldberg AB, Greenberg MB, Darney PD (2001) Misoprostol and pregnancy. N Engl J Med 344:38-47.

5. Blanchard K, Clark S, Winikoff B (2002) Misoprostol for women's health: a review. Ostet Gynecol 99:316-332.

6. Singh K, Fong YF (2000) Preperation of the cervix for surgical termination of pregnancy in the first trimester. Hum Reprod Update 6: $442-448$.

7. Bradley LD (2002) Complcations in hysteroscopy: prevention, treatment and legal risk. Curr Opin Obstet Gynecol 14: 409-415.

8. Hofmeyr GJ, Gulmezoglu AM (2003) Vaginal misoprostol for cervical ripening and labor induction of labour. Cochrane Database Syst Rev (1): CD000941.

9. O 'Brein P, EL-Rafaey H, Gordon A (1998) Rectally administered misoprostol for the treatment of post partum haemorrhage unresponsive to oxytocin and ergometrne: a descriptive study. Obstet Gynecol 92: 212-214.

\section{Your next submission with Juniper Publishers will reach you the below assets}

- Quality Editorial service

- Swift Peer Review

- Reprints availability

- E-prints Service

- Manuscript Podcast for convenient understanding

- Global attainment for your research

- Manuscript accessibility in different formats

( Pdf, E-pub, Full Text, Audio)

- Unceasing customer service

Track the below URL for one-step submission https://juniperpublishers.com/online-submission.php 